\title{
Metabolism of cellobiose by Clostridium cellulolyticum growing in continuous culture: evidence for decreased NADH reoxidation as a factor limiting growth
}

\author{
S. Payot, E. Guedon, C. Cailliez, E. Gelhaye and H. Petitdemange \\ Author for correspondence: H. Petitdemange. Tel: +33 3839120 53. Fax: +33 383912550. \\ e-mail : hpetitde@lcb.u-nancy.fr
}

Laboratoire de Chimie Biologique I, Université Henri Poincaré, Faculté des Sciences, BP 239, 54506 Vandoeuvre-lès-Nancy cedex, France

\begin{abstract}
Previous results indicated that molar growth yields are reduced when Clostridium cellulolyticum is cultured in media containing cellobiose concentrations greater than $1 \mathrm{~g} \mathrm{I}^{-1}$. Continuous cultures were examined to determine the physiological basis of these poor growth yields. Acetate was the main product of $C$. cellulolyticum metabolism, whereas the production of reduced compounds such as ethanol or lactate was low. Such patterns of product formation were accompanied by a 12-fold increase in intracellular NADH concentration when the cellobiose flow was increased. Catabolic enzymic activities were measured in vitro. Glyceraldehyde-3-phosphate dehydrogenase (GAPDH), acetate kinase and phosphoroclastic activities were found at similar levels as in cells metabolizing higher substrate concentrations. In contrast, lactate dehydrogenase activity was low and correlated with the rate of lactate production. Furthermore, an inhibition of GAPDH activity by high NADH/NAD + ratios was established. These results suggested that a decreased NADH reoxidation could be responsible for limiting $C$. cellulo/yticum growth. Lactate and ethanol production were not sufficient to balance out the NADH produced in the GAPDH step of glycolysis. One consequence of poor NADH reoxidation would be an increase in intracellular concentration of NADH, which in turn could inhibit GAPDH activity.
\end{abstract}

Keywords: Clostridium cellulolyticum, continuous culture, cellobiose, NADH/NAD ${ }^{+}$ ratio, growth inhibition

\section{INTRODUCTION}

Cellulose is the most abundant biopolymer on earth and is the chief component of plant biomass. A community of physiologically diverse micro-organisms is responsible for the anaerobic degradation of cellulose (Beguin \& Aubert, 1994). In most natural environments, mesophilic cellulolytic clostridia play a major role in cellulose decomposition (Leschine, 1995). Fundamental studies of cellulolytic clostridia were developed about 20 years ago and were devoted essentially to cellulase systems including the well-characterized cellulosome of Clostridium thermocellum (Beguin \& Aubert, 1994). The cellulosome, which is cell-associated, exhibits multiple functions, including both cell adhesion and hydrolysis of

Abbreviations: fd, ferredoxin; GAPDH, glyceraldehyde-3-phosphate dehydrogenase. lignocellulosic compounds (see Felix \& Ljungdahl, 1993; Bayer et al., 1996 for reviews). The cellulosome is considered to mediate the cohesive association of cellulases and xylanases and to promote their synergistic action, avoiding the production of free extracellular enzymes. It is clear that the efficiency of cellulose hydrolysis correlates with the population of cellulolytic bacteria and the tight adhesion of these bacteria to their substrate (Weimer, 1996). Bacterial growth on cellulose is rather difficult to follow (Gelhaye et al., 1993b) and most studies that focused on carbon metabolism in these bacteria were performed with cellobiose, the major endproduct of the degradation process, which is taken up and assimilated by the cells ( $\mathrm{Ng} \&$ Zeikus, 1982; Giallo et al., 1983; Strobel, 1995; Strobel et al., 1995).

Clostridium cellulolyticum ATCC 35319 was isolated from decayed grass (Petitdemange et al., 1984) and its growth cycle in contact with cellulose was described by 
Gelhaye et al. (1993a, b). As found with other cellulolytic clostridia, due to early inhibition of metabolism and growth, C. cellulyticum classically uses low quantities of sugar (Giallo et al., 1983; Cailliez et al., 1992). A mean value of $250 \mathrm{mg}$ dry weight cells $\mathrm{l}^{-1}$ was found for cultures grown with a cellobiose concentration of $2 \mathrm{~g} \mathrm{l}^{-1}$; above this value, no further increase in biomass occurred. In comparison with other clostridia such as C. butyricum or C. acetobutylicum, these values are low ; biomasses of 3-6 $\mathrm{g} \mathrm{l}^{-1}$ are usually obtained and 30-100 $\mathrm{g} \mathrm{l}^{-1}$ carbohydrate catabolized (Vasconcelos et al., 1994; Abbad-Andaloussi et al., 1995). No increase in growth yield was observed by increasing the concentration of either yeast extract or Casamino acids, and growth limitation was not the result of low $\mathrm{pH}$ due to acid formation (Giallo et al., 1983). Furthermore, end products have no inhibitory effect when added at concentrations equal to the final titres (Giallo et al., 1983).

The purpose of this research was to identify the factors responsible for this growth limitation and to examine the metabolism of C. cellulolyticum ATCC 35319 with cellobiose as growth substrate in continuous culture.

\section{METHODS}

Chemicals. All chemicals were reagent grade. Enzymes and coenzymes were obtained from Sigma. All gases used were purchased from Air Liquide.

Organism. C. cellulolyticum ATCC 35319, a mesophilic cellulolytic bacterium isolated from decayed grass (Petitdemange et al., 1984), was used.

Medium and culture conditions. The bacterium was grown anaerobically on a complex medium (CM3) (pH 7.8) containing $\left(1^{-1}\right): \mathrm{KH}_{2} \mathrm{PO}_{4}, 1.4 \mathrm{~g} ; \mathrm{K}_{2} \mathrm{HPO}_{4} .3 \mathrm{H}_{2} \mathrm{O}, 2.9 \mathrm{~g} ;\left(\mathrm{NH}_{4}\right)_{2} \mathrm{SO}_{4}$, $1.3 \mathrm{~g} ; \mathrm{MgCl}_{2} .6 \mathrm{H}_{2} \mathrm{O}, 0.1 \mathrm{~g} ; \mathrm{CaCl}_{2} .2 \mathrm{H}_{2} \mathrm{O}, 0.02 \mathrm{~g}$; yeast extract, $5 \mathrm{~g} ; 5 \%(\mathrm{w} / \mathrm{v}) \mathrm{FeSO}_{4}$ in $0.1 \mathrm{M} \mathrm{H}_{2} \mathrm{SO}_{4}, 25 \mu \mathrm{l}$; cysteine hydrochloride, $1 \mathrm{~g}$; and $0.2 \%(\mathrm{w} / \mathrm{v})$ resazurin, $0.5 \mathrm{ml}$.

The bacterium was routinely transferred into a medium containing 7.5 $\mathrm{g} \mathrm{l}^{-1}$ cellulose MN 300 (Serva Feinbiochemica). Routine transfers were also carried out in $9 \mathrm{ml}$ of medium supplemented with cellobiose (ICN Biochemicals) to a final concentration of $3 \mathrm{~g} \mathrm{l}^{-1}$.

The medium was reduced by the technique of Hungate (1969) and was dispensed under a constant flow of $\mathrm{N}_{2}$ in Hungate tubes (Bellco Glass) or 'penicillin flasks' before autoclaving for $20 \mathrm{~min}$ at $120^{\circ} \mathrm{C}$.

The anaerobic culture technique used was that proposed by Hungate (1969) as modified by Bryant (1972). Bacteria were grown at $34^{\circ} \mathrm{C}$ without shaking except in fermenter cultures.

Growth measurement. Growth was measured by reading optical density at $600 \mathrm{~nm}$ with a Beckman model 34 spectrophotometer. It was established that an optical density of 1 at $600 \mathrm{~nm}$ corresponded to a bacterial dry weight of $0.5 \mathrm{~g} \mathrm{l}^{-1}$ (Gehin et al., 1995).

Fermentation modes. For continuous culture experiments, CM3 medium was again used. It was prepared as follows: a solution containing 8.51 distilled water, $\mathrm{KH}_{2} \mathrm{PO}_{4}, \mathrm{~K}_{2} \mathrm{HPO}_{4}$, $\left(\mathrm{NH}_{4}\right)_{2} \mathrm{SO}_{4}, \mathrm{MgCl}_{2}$, cysteine hydrochloride and resazurin was autoclaved in a $10 \mathrm{l}$ glass flask. Yeast extract, $\mathrm{CaCl}_{2}, \mathrm{FeSO}_{4}$ and cellobiose were autoclaved separately and aseptically transferred with a peristaltic pump to the solution prepared as described earlier.

Continuous culture was carried out in a 21 fermenter (LSL BioLafitte) with a $1.5 !$ working volume maintained by overflow through a sidearm in the fermenter jar. The temperature was controlled at $34^{\circ} \mathrm{C}$ and medium $\mathrm{pH}$ was adjusted to $7 \cdot 2$ with $1 \mathrm{M} \mathrm{NaOH}$. The feed flask and fermenter were maintained under filter-sterilized nitrogen gas and the fermenter was gently stirred (50 r.p.m). The bioreactor was inoculated $(10 \%, v / v)$ with an exponential-phase preculture. The culture was grown in batch for $15 \mathrm{~h}$ before the medium flow was started. A period of three residence times was generally found to be sufficient to achieve steady-state values of the parameters measured. At least three samples were taken for each set of steady-state data points reported.

Analytical methods. Reducing sugars were determined by the method of Miller (1959) using cellobiose as the standard.

Ethanol, L-lactate and acetate were determined spectrophotometrically with enzyme kits (Boehringer Mannheim).

Preparation of cell-free extracts. Cells were centrifuged at $12000 \mathrm{~g}$ for $20 \mathrm{~min}$. After washing with Tris buffer $(50 \mathrm{mM}$

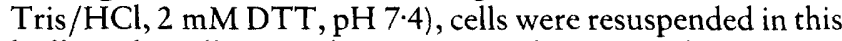
buffer. The cells were then sonicated four times for $20 \mathrm{~s}$ at a frequency of $20 \mathrm{kcycles} \mathrm{s}^{-1}$, separated by $60 \mathrm{~s}$ (MSE $150 \mathrm{~W}$ ultrasonic disintegrator). The supernatant was collected from the cell lysate following centrifugation at $12000 \mathrm{~g}$ for $20 \mathrm{~min}$ at $4{ }^{\circ} \mathrm{C}$. At each step, extracts were maintained under anaerobic conditions. Protein concentrations of cell extracts were determined according to the method of Bradford (1976) using crystalline BSA as the standard.

\section{Enzyme assays}

Ferredoxin $(\mathrm{fd})-\mathrm{NAD}(\mathrm{P})^{+}$reductase $[\mathrm{EC}$ 1.18.1.3 (EC 1.18.1.2)] was assayed with pyruvate as the reductant of $\mathrm{fd}$ and under a carbon monoxide atmosphere according to Petitdemange et al. (1976), modified by the addition of $1 \mathrm{mM}$ purified $\mathrm{fd}$.

$\mathrm{NADH}-\mathrm{fd}$ reductase was measured by metronidazole reduction according to the method of Blusson et al. (1981).

Hydrogenase (EC 1.18.99.1) in the direction of methyl viologen reduction was assayed as described by Junelles et al. (1988) with the following modifications: $60 \mathrm{mM}$ potassium

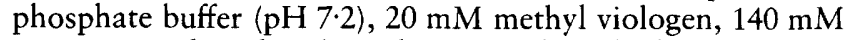
$\beta$-mercaptoethanol and incubation under a hydrogen atmosphere were used.

Phosphoroclastic activities. Assays were based on formation of acetyl phosphate during the oxidation of pyruvate, as described by Mortenson et al. (1963), with the following

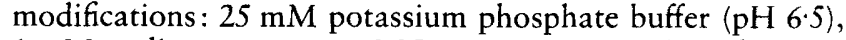
$1 \mathrm{mM}$ sodium pyruvate, $0.05 \mathrm{mM}$ coenzyme $A$ and $1 \mathrm{mM}$ methyl viologen were used.

Glyceraldehyde-3-phosphate dehydrogenase (GAPDH) (EC 1.2.1.12) activity was followed by the increase in $A_{340}$ according to the method of Ferdinand (1964).

Acetate kinase (EC 2.7.2.1) activity was determined by the analysis of acetylphosphate (Lipmann \& Tuttle, 1945). The reaction volume was $0.4 \mathrm{ml}$ and the reaction mixture contained: Tris $/ \mathrm{HCl}(\mathrm{pH} 7 \cdot 5), 100 \mathrm{mM}$; potassium acetate, $40 \mathrm{mM}$; manganese sulfate, $6 \mathrm{mM}$; ATP, $10 \mathrm{mM}$. The reac- 
tion was initiated by addition of cell-free extract. After $5 \mathrm{~min}$ at $37^{\circ} \mathrm{C}, 0.2 \mathrm{ml}$ of hydroxylamine $(700 \mathrm{mM}$ ), pH 6.4 (freshly neutralized), was added. After $5 \mathrm{~min}$ at room temperature, the reaction was stopped by addition of $0.2 \mathrm{ml}$ trichloroacetic acid $(15 \%, \mathrm{v} / \mathrm{v}), 0.2 \mathrm{ml} \mathrm{HCl}(4 \mathrm{M})$ and $0.2 \mathrm{ml} \mathrm{FeCl}_{3}(5 \% \mathrm{w} / \mathrm{v}$ in $0 \cdot 1 \mathrm{M} \mathrm{HCl}$ ). The amount of acetyl hydroxamate formed was determined by absorbance at $540 \mathrm{~nm}$ after centrifugation of the samples for $5 \mathrm{~min}$ at $12000 \mathrm{~g}$.

Alcohol dehydrogenase (EC 1.1.1.1) activity was determined by following $\mathrm{NAD}(\mathrm{P}) \mathrm{H}$-dependent acetaldehyde reduction at $340 \mathrm{~nm}$. The assay mixture contained $100 \mathrm{mM}$ potassium phosphate buffer ( $\mathrm{pH} 7.4), 0.2 \mathrm{mM} \mathrm{NAD}(\mathrm{P}) \mathrm{H}, 2 \mathrm{mM}$ DTT and $40 \mathrm{mM}$ acetaldehyde (Lamed \& Zeikus, 1980).

Lactate dehydrogenase (EC 1.1.1.27) activity was measured by following at $340 \mathrm{~nm}$ the $\mathrm{NAD}(\mathrm{P}) \mathrm{H}$-dependent reduction of pyruvate to lactate (Abbe et al., 1982). The assay mixture

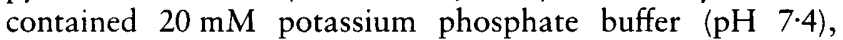
$0.4 \mathrm{mM} N \mathrm{NAD}(\mathrm{P}) \mathrm{H}, 1 \mathrm{mM}$ fructose 1,6-bisphosphate and $20 \mathrm{mM}$ pyruvate.

Extraction of nucleotides. NADH, NADPH, $\mathrm{NAD}^{+}, \mathrm{NADP}^{+}$, ATP and ADP levels were measured after extraction of culture broth samples. Samples of $10 \mathrm{ml}$ were rapidly removed from the bioreactor with sterile syringes and immediately put into tubes containing extractant. Cells were not separated from the medium except for the $\mathrm{NAD}^{+}$or $\mathrm{NADP}^{+}$assays. $\mathrm{NAD}^{+}$, $\mathrm{NADP}^{+}, \mathrm{ATP}$ and ADP were extracted with $\mathrm{HCl}$ (NADH and NADPH were degraded), NADH and NADPH were extracted with $\mathrm{KOH}\left(\mathrm{NAD}^{+}\right.$and $\mathrm{NADP}^{+}$were degraded), as described by Wimpenny \& Firth (1972). For $\mathrm{NAD}^{+}$and $\mathrm{NADP}^{+}$ determinations, cells were centrifuged and resuspended in deionized water to avoid medium interference during the fluorimetric assays. NADH was measured using a lactate dehydrogenase assay (Klingenberg, 1965), in which the decrease in fluorescence (Hitachi model F-2000 fluorometer) was proportional to the quantity of NADH. NAD ${ }^{+}$and $\mathrm{NADP}^{+}$ were assayed with a $\mathrm{NAD}(\mathrm{H})$-specific alcohol dehydrogenase and a glucose-6-phosphate dehydrogenase (EC 1.1.1.49), respectively (Klingenberg, 1965; Vasconcelos et al., 1994) and the resulting $\mathrm{NADH}$ or $\mathrm{NADPH}$ was determined by fluorimetry. NADPH was converted to $\mathrm{NADP}^{+}$using glutamate dehydrogenase (EC 1.4.1.4) (Klingenberg, 1965; Wimpenny $\&$ Firth, 1972) and $\mathrm{NADP}^{+}$was then determined as described before.

For ADP determinations, the ADP was converted to ATP by creatine phosphokinase (EC 2.7.3.2) in a reaction mixture containing $2 \mathrm{ml}$ supernatant, $7 \mathrm{mM}$ phosphocreatine in Tris/ $\mathrm{HCl}$ buffer $(0 \cdot 1 \mathrm{M}, \mathrm{pH} 7 \cdot 4), 0 \cdot 4 \mathrm{mM} \mathrm{MgSO}_{4}$ and $4 \mathrm{U}$ creatine phosphokinase from rabbit muscle maintained for $20 \mathrm{~min}$ at $30^{\circ} \mathrm{C}$. The reaction was stopped by addition of $6 \mathrm{M} \mathrm{HCl}(\mathrm{pH}$ $2 \cdot 0$ ) and the mixture centrifuged for $10 \mathrm{~min}$ at $12000 \mathrm{~g}$ before neutralization with $10 \mathrm{M} \mathrm{NaOH}$ and storage of the supernatant at $-80^{\circ} \mathrm{C}$. ATP was determined by bioluminescence using the luciferin-luciferase system (Microbial Biomass Reagent kit; Lumac). Experiments were made to verify complete ADP to ATP conversion under the conditions tested. ADP was calculated by subtracting the ATP values from the ADP plus ATP assay values and taking into account volume variations.

Measurement of glycogen and exopolysaccharides. Glycogen was assayed by the method of Robson et al. (1974).

Exopolysaccharides were separated from cells by centrifugation at $36000 \mathrm{~g}$ for $40 \mathrm{~min}$ in the presence of a chelating agent (10 $\mathrm{mM}$ tetrasodium EDTA) and $100 \mathrm{mM} \mathrm{NaCl}$. Super-

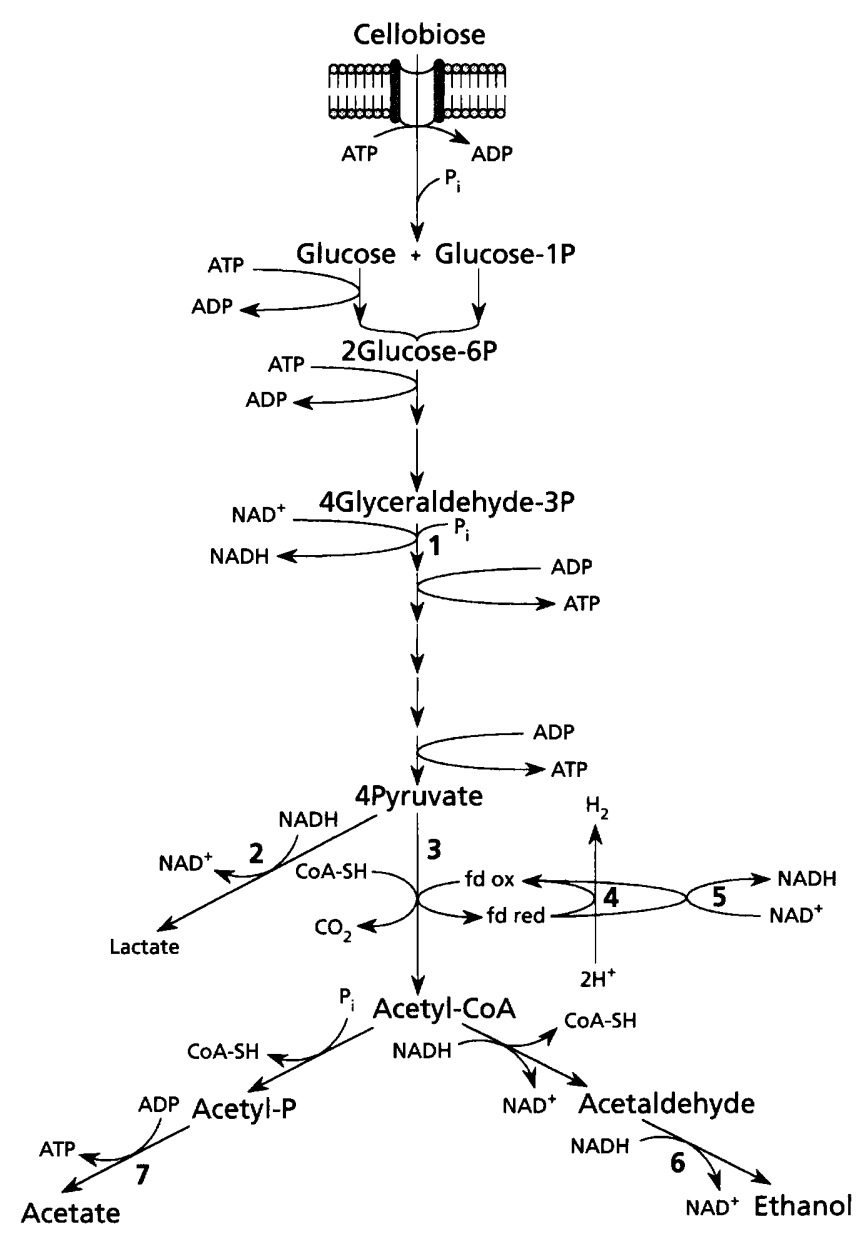

Fig. 1. Schematic diagram depicting the catabolism of cellobiose by $C$. cellulolyticum. 1, GAPDH; 2, lactate dehydrogenase; 3 , phosphoroclastic reaction; 4 , hydrogenase; 5, NADH-fd oxidoreductase; 6, alcohol dehydrogenase; 7, acetate kinase.

natant $(25 \mathrm{ml})$ was added to propan-2-ol $(75 \mathrm{ml})$. The precipitate was collected by centrifugation, dried for 24 h at $45^{\circ} \mathrm{C}$ and resuspended in distilled water. Polysaccharides were assayed by the method of Dubois et al. (1956).

Calculations. The main products of cellobiose fermentation by C. cellulolyticum were acetate, ethanol, lactate, $\mathrm{H}_{2}$ and $\mathrm{CO}_{2}$ (Giallo et al., 1983) (see Fig. 1).

If one assumes, as did Strobel (1995) and Strobel et al. (1995), who demonstrated in a cellulolytic bacterium, C. thermocellum, that the transport of cellodextrin, cellobiose and glucose requires an ATP molecule and that intracellular cellobiose is converted to glucose 1-phosphate and glucose by cellobiose phosphorylase (EC 2.4.1.20) (Schimz et al., 1983; Thurston et al., 1993; Wells et al., 1995), then the conversion of cellobiose to acetate can be written as:

cellobiose $+8 \mathrm{ADP}+8 \mathrm{P}_{\mathrm{i}}+4 \mathrm{NAD}^{+} \rightarrow$

4 acetate $+8 \mathrm{ATP}+4 \mathrm{NADH} 4 \mathrm{CO}_{2}+4 \mathrm{H}_{2}$

The conversion of cellobiose to ethanol can be written as:

cellobiose $+4 \mathrm{ADP}+4 \mathrm{P}_{\mathrm{i}}+4 \mathrm{NADH} \rightarrow$

4ethanol $+4 \mathrm{ATP}+4 \mathrm{NAD}^{+}+4 \mathrm{CO}_{2}+4 \mathrm{H}_{2}$ 
and the conversion of cellobiose to lactate as:

cellobiose $+4 \mathrm{ADP}+4 \mathrm{P}_{\mathrm{i}} \rightarrow$ 4lactate $+4 \mathrm{ATP}$

$\mathrm{NADH}$ is formed by GAPDH, and ATP is formed by phosphoglycerate kinase, pyruvate kinase and acetate kinase.

The specific rate of NADH production and NADH consumption were calculated as follows:

$q_{\mathrm{NADH} \text { produced }}=q_{\text {ethanol }}+q_{\text {acetate }}+q_{\text {lactate }}$

$q_{\mathrm{NADH} \text { consumed }}=2 q_{\text {ethanol }}+q_{\text {lactate }}$

where $q_{\text {acetate }}, q_{\text {ethanol }}$ and $q_{\text {lactate }}$ are the specific rates of product formation.

In the following sections, $q_{\text {cellobiose }}$ is the specific rate of cellobiose used in mmol ( $\mathrm{g}$ dry wt cells) $)^{-1} \mathrm{~h}^{-1}$ and $q_{\text {pyruvate }}=$ $q_{\text {lactate }}+q_{\text {acetate }}+q_{\text {ethanol }}$.

\section{RESULTS}

\section{Continuous culture on cellobiose as a function of dilution rate}

Fig. 2 illustrates the utilization of cellobiose and the steady-state biomass at various dilution rates $(D)$. At a cellobiose concentration in the feed medium of $2.34 \mathrm{mM}$ and over a wide range of low dilution rates (from 0.015 to $\left.0.080 \mathrm{~h}^{-1}\right)$, the residual cellobiose concentrations were low; above $0.080 \mathrm{~h}^{-1}$, the concentration increased and reached that in the inflow of the nutrition solution. These data are typical of a continuous culture carried out under carbon limitation. Continuous cultures were

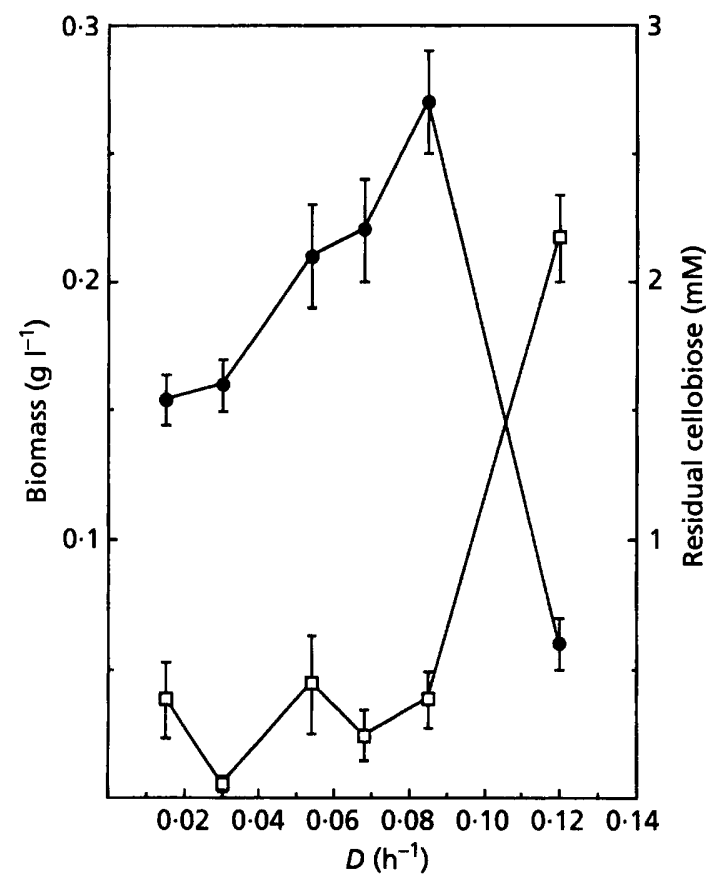

Fig. 2. Residual cellobiose concentration $(\square)$ and steady-state biomass concentration (O) as functions of the dilution rate. The cellobiose input concentration was $2.34 \mathrm{mM}$. Results presented are means $\pm \mathrm{SD}$ calculated from three different experiments.

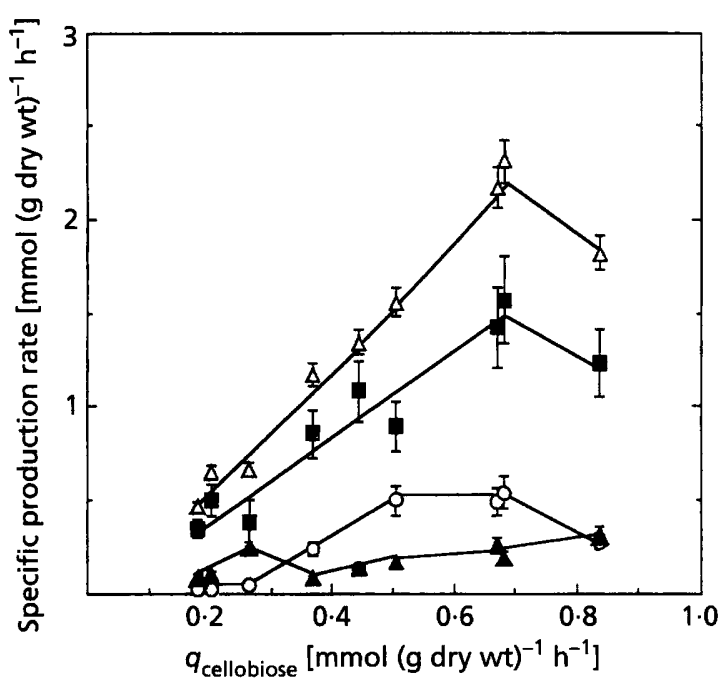

Fig. 3. Specific production rates of pyruvate $(\triangle)$, acetate ( $\square$ ), lactate $(O)$ and ethanol $(\boldsymbol{\Delta})$ as functions of the specific cellobiose uptake rate in cellobiose-limited continuous culture. Results presented are means \pm SD of three independent determinations from different cultures.

shown to be carbon-limited when the cellobiose concentration in the feed medium was less than $2.9 \mathrm{mM}$. Based on a plot of $1 / D$ versus $1 / Y_{\mathrm{ATP}}$, the maintenance cost was estimated to be $0.93 \mathrm{mmol} \mathrm{ATP} \mathrm{g}^{-1} \mathrm{~h}^{-1}$ (data not shown); this cost may be responsible for the decrease in biomass observed at low dilution rates.

\section{End-product formation}

The main product of $C$. cellulolyticum cellobiose metabolism was acetate at all the dilution rates tested. Acetate production reached a mean of $60 \%$ of the carbon flowing to products; the other $40 \%$ was distributed between lactate $(30 \%)$ and ethanol $(10 \%)$. The relationship of these distributions is shown in Fig. 3. Acetate formation was proportional to carbon flow in the first part of the curve, and decreased as carbon flow increased. Pyruvate formation showed the same pattern in relation to carbon flow. It can be concluded that above a critical carbon flow of $0.66 \mathrm{mmol}$ cellobiose $(\mathrm{g}$ dry wt cells $)^{-1} h^{-1}$, part of the flow did not proceed to the end of the glycolytic pathway, since the $q_{\text {pyruvate }}$ decreased while the $q_{\text {cellobiose }}$ increased. These data are consistent with cellobiose conversion to polymers (see below). Lactate formation was seen only when the carbon flow was greater than a $q_{\text {cellobiose }}$ value of $0.27 \mathrm{mmol}$ cellobiose ( $\mathrm{g}$ dry wt cells) ${ }^{-1} \mathrm{~h}^{-1}$. However, less lactate was produced than acetate. Its production parallelled acetate formation until it reached a maximal value at a $q_{\text {cellobiose }}$ of $0.5 \mathrm{mmol}$ cellobiose ( $\mathrm{g}$ dry wt cells) $)^{-1} \mathrm{~h}^{-1}$, and decreased at a $q_{\text {cellobiose }}$ greater than $0.68 \mathrm{mmol}$ cellobiose (g dry wt cells) -1 $^{-1} \mathrm{~h}^{-1}$. Ethanol production was always low and was not affected by high carbon flow. 
Table 1. Fermentation parameters for continuous steady-state cultures of $C$. cellulolyticum

Values for biomass and residual cellobiose concentrations are means $( \pm$ SD) of three different experiments. All other values are also means and had an SE of $\pm 10 \%$.

\begin{tabular}{|c|c|c|c|c|c|c|c|c|}
\hline$D\left(h^{-1}\right) \ldots$ & 0.015 & 0.030 & 0.030 & 0.054 & $0 \cdot 068$ & 0.075 & 0.080 & 0.085 \\
\hline Biomass concn $\left(\mathrm{g} \mathrm{l}^{-1}\right)$ & $0 \cdot 15(0.01)$ & $0 \cdot 16(0 \cdot 01)$ & $0.61(0.07)$ & $0 \cdot 21(0 \cdot 02)$ & $0.22(0 \cdot 02)$ & $0.32(0 \cdot 04)$ & $0.23(0.02)$ & $0.27(0.02)$ \\
\hline $\begin{array}{l}\text { Fed substrate concn } \\
(\mathrm{mM})\end{array}$ & $2 \cdot 34$ & $2 \cdot 34$ & $16 \cdot 67$ & $2 \cdot 34$ & $2 \cdot 34$ & $5 \cdot 85$ & $2 \cdot 92$ & $2 \cdot 34$ \\
\hline $\begin{array}{l}\text { Residual cellobiose } \\
\text { concn }(\mathrm{mM})\end{array}$ & $0 \cdot 38(0 \cdot 15)$ & $0.05(0.03)$ & $4.97(0.60)$ & $0.44(0.19)$ & $0.24(0 \cdot 10)$ & $2 \cdot 95(0 \cdot 30)$ & $1.02(0 \cdot 10)$ & $0 \cdot 38(0 \cdot 11)$ \\
\hline $\begin{array}{l}\text { Molar growth yield [g } \\
\text { cells (mol hexose })^{-1} \text { ] }\end{array}$ & 38 & 35 & 26 & 55 & 51 & 55 & 60 & 55 \\
\hline $\begin{array}{l}q_{\text {cellobiose }} \mid \mathrm{mmol}(\mathrm{g} \\
\left.\text { cells })^{-1} \mathrm{~h}^{-1}\right]\end{array}$ & $0 \cdot 196$ & 0.429 & 0.575 & 0.488 & 0.649 & 0.680 & $0 \cdot 661$ & $0 \cdot 617$ \\
\hline \multicolumn{9}{|l|}{$\begin{array}{l}\text { Product vield [mol (mol } \\
\left.\text { substrate })^{-1}\right]\end{array}$} \\
\hline Acetate & $2 \cdot 70$ & $2 \cdot 56$ & $1 \cdot 26$ & $1 \cdot 80$ & $2 \cdot 20$ & $1 \cdot 62$ & $2 \cdot 37$ & $1 \cdot 90$ \\
\hline Lactate & $0 \cdot 13$ & $0 \cdot 32$ & 0.61 & $1 \cdot 03$ & 0.75 & 0.96 & $0 \cdot 83$ & 0.50 \\
\hline Ethanol & $0 \cdot 58$ & 0.65 & $0 \cdot 22$ & $0 \cdot 34$ & $0 \cdot 39$ & $0 \cdot 36$ & $0 \cdot 31$ & $0 \cdot 45$ \\
\hline $\begin{array}{l}\mathrm{Y}_{\mathrm{ATP}}[\mathrm{g} \text { cells }(\mathrm{mol} \\
\text { ATP })^{-1} \mid\end{array}$ & $12 \cdot 5$ & $11 \cdot 5$ & $15 \cdot 5$ & $22 \cdot 2$ & $18 \cdot 9$ & $24 \cdot 2$ & $20 \cdot 6$ & $29 \cdot 0$ \\
\hline $\begin{array}{l}q_{\text {NADH produced }}[\mathrm{mmol}(\mathrm{g} \\
\left.\text { cells })^{-1} \mathrm{~h}^{-1}\right]\end{array}$ & $0 \cdot 65$ & $1 \cdot 34$ & $1 \cdot 21$ & $1 \cdot 56$ & $2 \cdot 17$ & $2 \cdot 00$ & $2 \cdot 31$ & 1.77 \\
\hline $\begin{array}{l}q_{\text {NADH used }}[\mathrm{mmol}(\mathrm{g} \\
\left.\text { cells })^{-1} \mathrm{~h}^{-1}\right]\end{array}$ & $0 \cdot 24$ & $0 \cdot 39$ & $0 \cdot 61$ & $0 \cdot 84$ & $1 \cdot 01$ & $1 \cdot 15$ & 0.93 & $0 \cdot 87$ \\
\hline$q_{\mathrm{NADH}}$ produced $/ q_{\mathrm{NADH}}$ used & $2 \cdot 70$ & $3 \cdot 40$ & $1 \cdot 98$ & $1 \cdot 85$ & $2 \cdot 14$ & $1 \cdot 73$ & $2 \cdot 48$ & $2 \cdot 03$ \\
\hline Carbon recovery $(\%)^{*}$ & $85 \cdot 2$ & $87 \cdot 7$ & $52 \cdot 0$ & $79 \cdot 2$ & $83 \cdot 5$ & $73 \cdot 5$ & $87 \cdot 7$ & $71 \cdot 2$ \\
\hline
\end{tabular}

"Carbon recovery was calculated as a function of the concentrations ( $\mathrm{mol} \mathrm{l}^{-1}$ ) of ethanol (E), acetic acid (A), lactic acid (L), feed or initial substrate $\left(\mathrm{S}_{\mathrm{o}}\right)$ and effluent or final substrate $\left(\mathrm{S}_{\mathrm{e}}\right)$ concentrations by using the following equation:

carbon recovery $=[3 \times(\mathrm{E}+\mathrm{L}+\mathrm{A})] /\left[12 \times\left(\mathrm{S}_{\mathrm{o}}-\mathrm{S}_{\mathrm{e}}\right)\right]$

assuming stoichiometric production of $\mathrm{CO}_{2}$ with acetic acid and ethanol. These values did not include cell carbon.

\section{Fermentation parameters}

Table 1 presents different parameters determined during continuous culture of C. cellulolyticum.

Maximal carbon flow supported by $C$. cellulolyticum was $0.68 \mathrm{mmol}$ cellobiose (g dry wt cells) ${ }^{-1} \mathrm{~h}^{-1}$ [equivalent to $11.3 \mathrm{nmol}$ cellobiose $\mathrm{min}^{-1}\left(\mathrm{mg}\right.$ cells) ${ }^{-1}$ or $22 \mathrm{nmol}$ cellobiose $\min ^{-1}$ (mg protein $)^{-1}$ ]. This value is in the same range reported for C. thermocellum $[18 \mathrm{nmol}$ cellobiose $\min ^{-1}$ (mg cells) ${ }^{-1} ; \mathrm{Ng} \&$ Zeikus, 1982] or Clostridium thermohydrosulfuricum $[24 \mathrm{nmol}$ cellobiose $\min ^{-1}$ (mg cells) ${ }^{-1}$; Ng \& Zeikus, 1982]. Higher values have been reported for another cellulolytic bacterium, Fibrobacter succinogenes $\left[76 \mathrm{nmol} \mathrm{min}{ }^{-1}\right.$ (mg protein) ${ }^{-1}$; Wells et al., 1995] and for a rumen bacterium, Prevotella ruminicola $\left[175 \mathrm{nmol} \mathrm{min}^{-1}(\mathrm{mg}\right.$ cells) $^{-1}$; Lou et al., 1996].

The highest molar growth yield obtained in this work was $60 \mathrm{~g}$ cells (mol hexose) ${ }^{-1}[0.2 \mathrm{~g}$ protein (g carbohydrate $)^{-1}$. This value is higher than those reported for C. thermocellum $\left.[38 \mathrm{~g} \text { (mol hexose })^{-1}\right]$ and C. thermobydrosulfuricum $\left[19 \mathrm{~g}\right.$ (mol hexose) ${ }^{-1} ; \mathrm{Ng} \&$ Zeikus, $1982]$ but in the same range as that of $P$. ruminicola [0.19 $\mathrm{g}$ protein (g carbohydrate) $\left.{ }^{-1}\right]$. In batch cultures a molar growth yield of $40 \mathrm{~g}$ cells (mol hexose) ${ }^{-1}$ was reported (Giallo et al., 1983).

A mean value of $19 \mathrm{~g}$ cells $(\mathrm{mol} \mathrm{ATP})^{-1}$ was obtained except at low dilution rates where a lower value was found. This decrease reflected an expenditure of energy due to the maintenance energy being more pronounced when the growth rate is low. In batch cultures of $C$. cellulolyticum a lower value was reported for $\mathrm{Y}_{\text {ATP }}[15 \mathrm{~g}$ cells (mol ATP) ${ }^{-1}$ ] (Giallo et al., 1983).

These high values of $Y_{\text {ATP }}$ are consistent with the fact that the high level of acetate production was accompanied by the highest level of ATP formation. However, this pattern of product formation (i.e. the high level of acetate production and the low level of lactate and ethanol production) coincided with an excess of NADH since the ratio $q_{\mathrm{NADH}}$ produced $/ q_{\mathrm{NADH}}$ used was always greater than one, ranging from 1.73 to 3.40 (Table 1 ).

Carbon recoveries obtained for continuous culture of $C$. cellulolyticum were between 71 and $87 \%$ (with one exception, $52 \%$ ), consistent with values found generally for cellulolytic bacteria (Lamed \& Zeikus, 1980; Giallo et al., 1983). They did not include cells since it is difficult to estimate the part of cellobiose devoted to biomass 
Table 2. Nucleotide levels in continuous steady-state cultures of $C$. cellulolyticum

Dilution rates and cellobiose input concentrations for experiments I-IV were $0.030 \mathrm{~h}^{-1}$ and $2.34 \mathrm{mM}, 0.030 \mathrm{~h}^{-1}$ and $16.67 \mathrm{mM}, 0.080 \mathrm{~h}^{-1}$ and $2.92 \mathrm{mM}$, and $0.075 \mathrm{~h}^{-1}$ and $5.85 \mathrm{mM}$, respectively. Values are means $( \pm \mathrm{SD})$ calculated from triplicate experiments.

\begin{tabular}{|lcccc|}
\hline Nucleotide & \multicolumn{4}{c|}{ Concentration $\left[\mu \mathrm{mol}(\mathrm{g} \text { dry cell mass })^{-1}\right.$ ] } \\
\cline { 2 - 5 } & Expt I & Expt II & Expt III & Expt IV \\
\hline NAD $^{+}$ & $0.5(0 \cdot 1)$ & $1 \cdot 0(0 \cdot 1)$ & $0 \cdot 7(0.1)$ & $0 \cdot 9(0 \cdot 2)$ \\
NADP $^{+}$ & $0 \cdot 3(0 \cdot 1)$ & $0 \cdot 8(0 \cdot 1)$ & $0 \cdot 6(0 \cdot 1)$ & $0 \cdot 3(0 \cdot 1)$ \\
NADH & $3.0(0 \cdot 5)$ & $15 \cdot 9(3 \cdot 0)$ & $40 \cdot 0(6 \cdot 0)$ & $37 \cdot 5(3 \cdot 5)$ \\
NADPH & $<0 \cdot 2^{*}$ & $<0 \cdot 2^{*}$ & $<0 \cdot 2^{*}$ & $<0 \cdot 2^{*}$ \\
ATP & $1 \cdot 0(0 \cdot 1)$ & $1 \cdot 8(0 \cdot 2)$ & $1 \cdot 9(0 \cdot 2)$ & $1 \cdot 8(0 \cdot 2)$ \\
ADP & $5 \cdot 7(0 \cdot 3)$ & $4 \cdot 2(0 \cdot 4)$ & $3 \cdot 0(0 \cdot 2)$ & $4 \cdot 1(0 \cdot 2)$ \\
\hline
\end{tabular}

$*$ Values less than detection level.

production on complex medium. Lowest values were found for chemostats conducted on $5.85 \mathrm{mM}$ cellobiose at $0.075 \mathrm{~h}^{-1}$ or on $2.34 \mathrm{mM}$ cellobiose at $0.085 \mathrm{~h}^{-1}$. Assays for glycogen synthesis revealed a significantly higher glycogen storage in cells from these chemostats [ 75 and $80 \mathrm{mg}$ glucose eq. (g cells) ${ }^{-1}$, respectively versus $5 \mathrm{mg}$ glucose eq. (g cells) ${ }^{-1}$ on $2.34 \mathrm{mM}$ cellobiose at $0.030 \mathrm{~h}^{-1}$ ] (data not shown). However, a glycogen storage of $60 \mathrm{mg}$ glucose eq. $(\mathrm{g} \text { cells })^{-1}$ did not account completely for the loss in carbon recovery (only $52 \%$ ) observed for cells from chemostats conducted on $16.67 \mathrm{mM}$ cellobiose at $0.030 \mathrm{~h}^{-1}$. Microscopic observation revealed a polysaccharidic network where cells were embedded which should account for the low values observed in carbon recovery. Several procedures have been tested to measure these exopolysaccharides. No one gave satisfactory results. An interference, probably due to a component of the complex CM3 medium used, must be responsible for the results obtained (high background and non-reproducibility). Furthermore, filtration or dialysis of the samples did not remove this interference.

\section{Nucleotide levels}

These were determined in four cases: at low or high dilution rate under carbon-limitation (experiments I and III, respectively, Table 2) or carbon-excess (experiments II and IV, respectively, Table 2). Whereas the total pool size of NADPH and NADP ${ }^{+}$of cells grown with different carbon flows was quite constant, the NADH concentration dramatically increased with the carbon flow. Increasing cellobiose concentration at $\mu=0.030 \mathrm{~h}^{-1}$ led to an increase in NADH concentration; starting from usual values such as $3.0 \mu \mathrm{mol}\left(\mathrm{g}\right.$ cells) ${ }^{-1}$ [experiment $\mathrm{I}$, Table 2, $q_{\text {ceillobiose }}=0.429 \mathrm{mmol}$ cellobiose $(\mathrm{g}$ dry wt cells $)^{-1} \mathrm{~h}^{-1}$ ], it reached values of $15.9 \mu \mathrm{mol}(\mathrm{g} \text { cells })^{-1}$ [experiment II, Table $2, q_{\text {cellobiose }}=0.575 \mathrm{mmol}$ cellobiose (g dry wt cells $\left.)^{-1} \mathrm{~h}^{-1}\right]$. Similar values $[40$ and $37.5 \mu \mathrm{mol}\left(\mathrm{g} \mathrm{cells}^{-1}\right.$ ] were obtained at $0.080 \mathrm{~h}^{-1}$ [experiment III, $q_{\text {cellobiose }}=0.661 \mathrm{mmol}$ cellobiose ( $\mathrm{g}$ dry wt cells) ${ }^{-1} \mathrm{~h}^{-1}$ ] and $0.075 \mathrm{~h}^{-1}$ [experiment IV, $q_{\text {cellobiose }}$ $=0.680 \mathrm{mmol}$ cellobiose (g dry wt cells) ${ }^{-1} \mathrm{~h}^{-1}$ ] when cellobiose concentration was increased from $2.92 \mathrm{mM}$ to $5.85 \mathrm{mM}$, indicating the saturation of the phenomenon observed (i.e. an increase of the NADH concentration with the specific rate of cellobiose consumption).

In spite of the fact that acetate formation was associated with ATP production, no significant variation was noted in the total pool size of ATP and ADP.

\section{Enzymic activities}

In the four cases described previously, enzymic activities were determined from cell extracts (Table 3). GAPDH and acetate kinase were found to be in the same range as activities previously described for bacteria metabolizing high concentrations of carbohydrate (Andersch et al., 1983; Hüsemann \& Papoutsakis, 1989; Girbal et al., 1995a; Abbad-Andaloussi et al., 1996). Lactate dehydrogenase and ethanol dehydrogenase exhibited almost no activity with $\mathrm{NADP}^{+}$. Lactate dehydrogenase activity was shown to be low but correlated with the rate of lactate formation. By comparison, activities reported for other bacteria were 3- to 10-fold higher (Lamed \& Zeikus, 1980; Lovitt et al., 1988). By contrast, alcohol dehydrogenase activity determined in vitro was not affected by carbon flow; values reported were lower than those described for C. thermocellum or C. thermo-

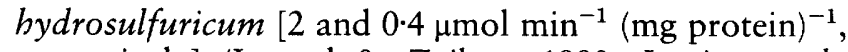
respectively] (Lamed \& Zeikus, 1980; Lovitt et al., 1988). In these conditions, the low lactate and ethanol production must be balanced by $\mathrm{H}_{2}$ gas formation via the $\mathrm{NAD}(\mathrm{P}) \mathrm{H}-\mathrm{fd}$ oxidoreductases, the physiological role of which could be to regenerate the reducing equivalents (Thauer et al., 1971). fd-NADP ${ }^{+}$reductase activities were much higher than the fd-NAD ${ }^{+}$reductase activities, which were hardly detectable. In contrast, high NADH-fd reductase activities $[0.074 \mu \mathrm{mol} \mathrm{min}-1$ (mg protein $)^{-1}$ ] were found for cells that exhibit a high 
Table 3. Enzymic activities from cell extracts of continuous cultures of $C$. cellulolyticum

Dilution rates and cellobiose input concentrations for experiments I-IV were $0.030 \mathrm{~h}^{-1}$ and $2.34 \mathrm{mM}, 0.030 \mathrm{~h}^{-1}$ and $16.67 \mathrm{mM}, 0.080 \mathrm{~h}^{-1}$ and $2.92 \mathrm{mM}$, and $0.075 \mathrm{~h}^{-1}$ and $5.85 \mathrm{mM}$, respectively. Values are means $( \pm S D)$ calculated from triplicate experiments.

\begin{tabular}{|lcccc|}
\hline \multirow{2}{*}{ Enzyme } & \multicolumn{3}{c|}{ Specific activity $\left[\mu \mathrm{mol} \mathrm{min}^{-1}\left(\mathrm{mg} \mathrm{protein}^{-1}\right)\right]$} \\
\cline { 2 - 5 } & Expt I & Expt II & Expt III & Expt IV \\
\hline GAPDH & $3.9(0.5)$ & $5.9(0.2)$ & $3.4(0.5)$ & $3.7(0.2)$ \\
Phosphoroclastic activity & $0.092(0.008)$ & $0.024(0.001)$ & $0.031(0.003)$ & $0.024(0.001)$ \\
Hydrogenase & $0.85(0.19)$ & $2.00(0.30)$ & $0.25(0.05)$ & $0.29(0.05)$ \\
Lactate dehydrogenase & $0.038(0.008)$ & $0.014(0.002)$ & $0.110(0.020)$ & $0.180(0.020)$ \\
Acetate kinase & $2.6(0.2)$ & $5.7(0.4)$ & $2.4(0.3)$ & $1.6(0.1)$ \\
Alcohol dehydrogenase & $0.22(0.01)$ & $0.20(0.03)$ & $0.28(0.02)$ & $0.34(0.08)$ \\
fd-NADP reductase & $0.003(0.001)$ & $0.004(0.001)$ & $0.027(0.001)$ & $0.025(0.005)$ \\
NADH-fd reductase & $0.015(0.002)$ & $0.050(0.010)$ & $0.074(0.015)$ & $0.074(0.018)$ \\
\hline
\end{tabular}

$\mathrm{NADH}$ content and data on NADH-fd reductase activities showed a direct correlation between the specific activities, which increased from 0.015 to $0.074 \mu \mathrm{mol} \mathrm{min}^{-1}$ (mg protein) $)^{-1}$, and the NADH content of the cell. NADH-fd reductase activity was higher than that described for C. acetobutylicum, Clostridium tyrobutyricum or C. thermo-

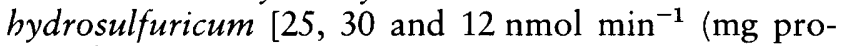
tein $)^{-1}$, respectively] but lower than the value reported for Clostridium pasteurianum $\left[171 \mathrm{nmol} \mathrm{min}^{-1}\right.$ ( $\mathrm{mg}$ protein) $)^{-1}$ ] (Petitdemange et al., 1976; Lovitt et al., 1988). The function of pyridine nucleotide oxidoreductases depends on both the bacterial species and strain and the specific growth conditions of a given strain (Petitdemange et al., 1976; Girbal et al., 1995a). With a hardly detectable fd- $-\mathrm{NAD}^{+}$reductase activity and a high NADH-fd reductase activity, the enzyme can function in $\mathrm{NADH}$ oxidation and $\mathrm{H}_{2}$ production via the hydrogenase. Hydrogenase activities were found to be higher at low dilution rates (experiments I and II, Table 3 ) and significantly higher in carbon excess at low dilution rate (experiment II) than under carbon limitation or excess at high dilution rates (experiments III and IV). However, it remained weak when compared with activities described for other bacteria [for example, $37 \mu \mathrm{mol} \mathrm{m^{-1 }}$ (mg protein) ${ }^{-1}$ for C. thermobydrosulfuricum (Lovitt et al., 1988) or $74 \mu \mathrm{mol} \mathrm{min}^{-1}$ (mg protein) ${ }^{-1}$ for C. thermocellum AS 39 (Lamed \& Zeikus, 1980)] even at high dilution rates where a high activity would be required to regenerate $\mathrm{NADH}$ via the $\mathrm{NADH}-\mathrm{fd}$ reductase activity. Because the NADH-fd reductase activity is interconnected with hydrogenase, the decrease in hydrogenase activity could affect the efficiency of this $\mathrm{NAD}^{+}$regenerating system and lead to an increase in the NADH pool. Phosphoroclastic activity was significantly lower under carbon saturation conditions and at high dilution rates corresponding to the higher detected intracellular NADH concentrations. This could be a way for the cells to limit acetate production and to make easier the reoxidation of NADH via lactate production.

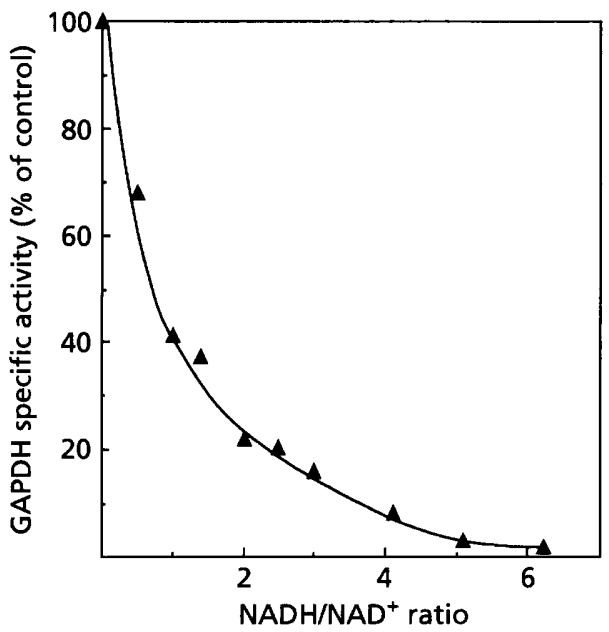

Fig. 4. Influence of the $\mathrm{NADH} / \mathrm{NAD}^{+}$ratio on $\mathrm{GAPDH}$ activity determined in vitro. Data points indicate residual activity in the presence of the given NADH/NAD ${ }^{+}$ratio. Control $(100 \%)$ activity was $1.2 \mu \mathrm{mol} \min ^{-1}(\mathrm{mg} \text { protein })^{-1}$. The concentration of $\mathrm{NAD}^{+}$was $0.1 \mathrm{mM}$.

The effect of NADH on GAPDH activity was determined to explain how high cellular $\mathrm{NADH} / \mathrm{NAD}^{+}$ ratios inhibited catabolism. In these experiments, arsenate was added to the GAPDH assay system since this competes with phosphate and forms an unstable intermediate which rapidly decomposes. 1,3-Biphosphoglycerate never accumulates and a significant reverse reaction is not possible (Krebs, 1955; Krebs et al., 1969; Blusson et al., 1981; Hyun et al., 1983). Under these assay conditions, it is possible to observe the effect of $\mathrm{NADH}$ as an effector rather than a substrate for the reverse reaction. The results (Fig. 4) show that, as the level of $\mathrm{NADH}$ was increased, the rate of $\mathrm{NAD}^{+}$ reduction by GAPDH activity was significantly inhibited. These data indicate that GAPDH activity is significantly inhibited when the $\mathrm{NADH} / \mathrm{NAD}^{+}$ratio is greater than 1. 


\section{DISCUSSION}

Cellobiose metabolism by C. cellulolyticum has thus far been studied only in batch cultures (Giallo et al., 1983; Gehin et al., 1995). This cellulolytic bacterium is able to metabolize completely only a small quantity of soluble carbohydrate $\left(3 \mathrm{~g} \mathrm{l}^{-1}\right)$. The molar growth yields were reduced when the initial cellobiose concentration exceeded $2 \mathrm{~g} \mathrm{l}^{-1}$; sugars were consumed without an increase in cell density (Giallo et al., 1983). To determine the physiological basis for growth limitation in $C$. cellulolyticum, we have now grown the cells in continuous culture with cellobiose as substrate.

The results presented in this paper suggest that growth of C. cellulolyticum is limited due to a low rate of $\mathrm{NADH}$ reoxidation leading to an intracellular accumulation of the reduced nucleotide. As described previously for batch cultures (Giallo et al., 1983), acetate is the main product of C. cellulolyticum cellobiose metabolism in continuous culture. Acetate formation was found to increase with increasing carbon flow, leading to high ATP production and to an insufficient rate of NADH regeneration. Production of reduced compounds such as ethanol and lactate was not sufficient to compensate for the slow rate of $\mathrm{NADH}$ reoxidation. An alternative method for $\mathrm{NAD}^{+}$regeneration from $\mathrm{NADH}$ in clostridia is by means of the NADH-fd oxidoreductase, which catalyses the electron flow from NADH $\left(E_{0}^{\prime}=\right.$ $-320 \mathrm{mV})$ via $\mathrm{fd}$ to protons $\left(E_{0}^{\prime}=-420 \mathrm{mV}\right)$. This reaction is thermodynamically unfavourable under standard conditions (Jungermann et al., 1973) and needs interspecies $\mathrm{H}_{2}$ transfer to be efficient (Wolin \& Miller, 1988; Morvan et al., 1996). The low rate of reoxidation of the excess reducing equivalents produced during glycolysis resulted in an approximatively 12 -fold increase in the intracellular NADH concentration. Similar $\mathrm{NADH}$ accumulation has been reported previously in $C$. acetobutylicum (sevenfold) (Girbal et al., 1995b) and in C. butyricum (eightfold) (Abbad-Andaloussi et al., 1996). Our results demonstrate that the high NADH/ $\mathrm{NAD}^{+}$ratio inhibits the in vitro activity of GAPDH, suggesting a possible limitation of the carbon flow as described previously in several other clostridia (Lovitt $e t$ al., 1988; Girbal \& Soucaille, 1994; Girbal et al., 1995b). However, the high in vitro GAPDH activity could be sufficient to ensure the carbon flow measured in cellobiose-saturated conditions $\left[q_{\text {cellobiose }}=0.680 \mathrm{mmol}\right.$ cellobiose (g dry wt cells) ${ }^{-1} \mathrm{~h}^{-1}$ (Table 1), corresponding to a GAPDH specific activity of $3.7 \mu \mathrm{mol} \mathrm{min}^{-1}$ (mg protein $)^{-1}$ (Table 3 ). The value of $q_{\text {pyruvate }}$ expressed in $\mu \mathrm{mol} \mathrm{min}^{-1}$ (mg protein) ${ }^{-1}$ was 0.073 i.e. $2 \%$ of the in vitro detected GAPDH activity, a value obtained at high $\mathrm{NADH} / \mathrm{NAD}^{+}$ratio (Fig. 4)]. These data suggest that $\mathrm{C}$. cellulolyticum is not able to metabolize high quantities of soluble sugars under these growth conditions.

Our data demonstrated that, at least on complex medium in continuous culture, C. cellulolyticum is not able to cope with carbon overflow by, for example, inducing lactate production. C. cellulolyticum and many other clostridia show lactate dehydrogenase activity, but lactic acid is not normally a major end product (Russell et al., 1996). Furthermore, many clostridia, such as $C$. acetobutylicum, are able to induce metabolic shift to produce solvents (ethanol, butanol or acetone). This metabolic shift is associated with high intracellular ATP and $\mathrm{NAD}(\mathrm{P}) \mathrm{H}$ contents. In particular, solvent production in C. acetobutylicum is induced under conditions of low ATP requirement, high ATP availability and high intracellular NADH content (see Girbal et al., 1995b for a review). Our results show that under similar conditions, C. cellulolyticum is not able to induce metabolic shift to produce reduced compounds such as ethanol.

These results described in this paper concerning carbon metabolism by a mesophilic cellulolytic clostridium have to be considered in relation to the natural environment of the bacterium. In previous studies, we have shown that growth of C. cellulolyticum occurs as the cells adhere to cellulose fibres (Gelhaye et al., 1993a, b). In this context, the cellulose is usually coated by other polymers, predominantly xylan and lignin, which hinder cellulolysis. Our results suggest that catabolism in C. cellulolyticum is adapted to low carbon flows, consistent with the notion that high concentrations of soluble sugars, such as 2 or $3 \mathrm{~g} \mathrm{l}^{-1}$, are probably not found in natural ecosystems. Furthermore, in many ecosystems where lignocellulose compounds are degraded, interspecies hydrogen transfer occurs and the $\mathrm{H}_{2}$ produced by cellulolytic bacteria, such as C. cellulolyticum, is used immediately by methanogens or other $\mathrm{H}_{2}$-using species (Wolin \& Miller, 1988; Morvan et al., 1996). Given that $\mathrm{H}_{2}$ does not accumulate, the formation of $\mathrm{H}_{2}$ from NADH would not be inhibited and the bacteria would not need to produce reduced compounds (e.g. ethanol) to reoxidize the $\mathrm{NADH}$ produced during glycolysis. Thus, we demonstrate that in pure culture $C$. cellulolyticum, producing mainly acetate, $\mathrm{CO}_{2}$ and $\mathrm{H}_{2}$, is not adapted to high carbon flow catabolism.

To the best of our knowledge, this study is the first on cellobiose catabolism in free-living mesophilic cellulolytic clostridia. We showed that the catabolic enzymic activities detected in vitro were high compared to the low carbon flow measured in vivo in C. cellulolyticum. Indeed, the GAPDH, phosphoroclastic and acetate kinase activities detected in vitro are in the same range as values reported for clostridia such as C. acetobutylicum (Girbal et al., 1995a) or C. butyricum (AbbadAndaloussi et al., 1996) metabolizing high concentrations of carbohydrate. Since, in any ecosystem, a cellulolytic microbe exists in proximity to other microorganisms, these high enzymic activities could be a way for the cellulolytic clostridium to seize the small amounts of carbohydrates provided by cellulose degradation and so to compete efficiently with non-cellulolytic bacteria.

\section{ACKNOWLEDGEMENTS}

This work was supported by the commission of European Communities FAIR programme [contract no. CT 95-091 (DG 12 SSMA)]. 
The authors thank Michel Quittelier for his technical assistance.

\section{REFERENCES}

Abbad-Andaloussi, S., Manginot-Durr, C., Amine, J., Petitdemange, E. \& Petitdemange, H. (1995). Isolation and characterization of mutants of Clostridium butyricum DSM 5431 with increased resistance to 1,3-propanediol and altered production of acids. Appl Environ Microbiol 61, 4413-4417.

Abbad-Andaloussi, S., Durr, C., Raval, G. \& Petitdemange, H. (1996). Carbon and electron flow in Clostridium butyricum grown in chemostat culture on glycerol and on glucose. Microbiology 142, 1149-1158.

Abbe, K., Takahashi, S. \& Yamada, T. (1982). Involvement of oxygen-sensitive pyruvate formate-lyase in mixed-acid fermentation by Streptococcus mutans under strictly anaerobic conditions. J Bacteriol 152, 175-182.

Andersch, W., Bahl, H. \& Gottschalk, G. (1983). Level of enzymes involved in acetate, butyrate, acetone and butanol formation by Clostridium acetobutylicum. Eur J Appl Microbiol Biotechnol 18, $327-332$.

Bayer, E. A., Morag, E., Shoham, Y., Tormo, J. \& Lamed, R. (1996). The cellulosome: a cell surface organelle for the adhesion to and degradation of cellulose. In Bacterial Adbesion: Molecular and Ecological Diversity, pp. 155-182. Edited by M. Fletcher. New York: Wiley-Liss.

Beguin, P. \& Aubert, J.-P. (1994). The biological degradation of cellulose. FEMS Microbiol Rev 13, 25-58.

Blusson, H., Petitdemange, H. \& Gay, R. (1981). A new, fast and sensitive assay for $\mathrm{NADH}-$ ferredoxin oxidoreductase detection in Clostridia. Anal Biochem 110, 176-181.

Bradford, M. M. (1976). A rapid and sensitive method for quantitation of microgram quantities of protein utilizing the principles of protein-dye binding. Anal Biochem 72, 248-254.

Bryant, M. P. (1972). Commentary on the Hungate technique for culture of anaerobic bacteria. Am J Clin Nutr 25, 1324-1328.

Cailliez, C., Benoit, L., Thirion, J.-P. \& Petitdemange, H. (1992). Characterization of 10 mesophilic cellulolytic Clostridia isolated from a municipal solid waste digestor. Curr Microbiol 25, 105-112.

Dubois, M., Gilles, K. A., Hamilton, J. K., Rebers, P. A. \& Smith, F. (1956). Colorimetric method for determination of sugars and related substances. Anal Chem 28, 350-356.

Felix, C. R. \& Ljungdahl, L. G. (1993). The cellulosome: the exocellular organelle of Clostridium. Annu Rev Microbiol 47, 791-819.

Ferdinand, W. (1964). The isolation and specific activity of rabbitmuscle glyceraldehyde phosphate dehydrogenase. Biochem $J$ 92, 578-585.

Gehin, A., Gelhaye, E., Raval, G. \& Petitdemange, H. (1995). Clostridium cellulolyticum viability and sporulation under cellobiose starvation conditions. Appl Environ Microbiol 61, 868-871.

Gelhaye, E., Gehin, A. \& Petitdemange, H. (1993a). Colonization of crystalline cellulose by Clostridium cellulolyticum ATCC 35319. Appl Environ Microbiol 59, 3154-3156.

Gelhaye, E., Petitdemange, H. \& Gay, R. (1993b). Adhesion and growth rate of Clostridium cellulolyticum ATCC 35319 on crystalline cellulose. J Bacteriol 175, 3452-3458.

Giallo, J., Gaudin, C., Belaich, J.-P., Petitdemange, E. \& CailletMangin, F. (1983). Metabolism of glucose and cellobiose by cellulolytic mesophilic Clostridium sp. strain H10. Appl Environ Microbiol 45, 843-849.

Girbal, L. \& Soucaille, P. (1994). Regulation of Clostridium acetobutylicum metabolism as revealed by mixed-substrate steady-state continuous cultures: role of $\mathrm{NADH} / \mathrm{NAD}$ ratio and ATP pool. J Bacteriol 176, 6433-6438.

Girbal, L., Vasconcelos, I., Saint-Amans, S. \& Soucaille, P. (1995a). How neutral red modified carbon and electron flow in Clostridium acetobutylicum grown in chemostat culture at neutral pH. FEMS Microbiol Rev 16, 151-162.

Girbal, L., Croux, C., Vasconcelos, I. \& Soucaille, P. (1995b). Regulation of metabolic shifts in Clostridium acetobutylicum ATCC 824. FEMS Microbiol Rev 17, 287-297.

Hungate, R. E. (1969). A roll tube method for cultivation of strict anaerobes. Methods Microbiol 33, 117-132.

Hüsemann, M. H. W. \& Papoutsakis, E. T. (1989). Comparison between in vivo and in vitro enzyme activities in continuous and batch culture fermentations of Clostridium acetobutylicum. Appl Microbiol Biotechnol 30, 585-595.

Hyun, H. H., Zeikus, J. G., Longin, R., Millet, J. \& Ryter, A. (1983). Ultrastructure and extreme heat resistance of spores from thermophilic Clostridium species. J Bacteriol 156, 1332-1337.

Junelles, A. M., Janati-Idrissi, R., Petitdemange, H. \& Gay, R. (1988). Iron effect on acetone-butanol fermentation. Curr Microbiol 17, 299-303.

Jungermann, K., Thauer, R. K., Leimenstoll, G. \& Decker, K. (1973). Function of reduced pyridine nucleotide-ferredoxin oxidoreductases in saccharolytic Clostridia. Biochim Biophys Acta 305, 268-280.

Klingenberg, M. (1965). Spectrophotometric and fluorimetric methods: nicotinamide adenine dinucleotides $\left(\mathrm{NAD}^{+}, \mathrm{NADH}\right.$, $\left.\mathrm{NADP}^{+}, \mathrm{NADPH}\right)$. In Methods of Enzymatic Analysis vol. 4, 2nd edn, pp. 2045-2059. Edited by H. U. Bergmeyer. New York \& London: Academic Press.

Krebs, E. G. (1955). Glyceraldehyde-3-phosphate dehydrogenase from yeast. Methods Enzymol 1, 407-411.

Krebs, H. A., Freedland, R. A., Hems, R. \& Stubbs, M. (1969). Inhibition of hepatic gluconeogenesis by ethanol. Biochem J 112, 117-124.

Lamed, R. \& Zeikus, J. G. (1980). Ethanol production by thermophilic bacteria : relationship between fermentation product yields of and catabolic enzyme activities in Clostridium thermocellum and Thermoanaerobium brockii. J Bacteriol 144, 569-578.

Leschine, S. B. (1995). Cellulose degradation in anaerobic environments. Annu Rev Microbiol 49, 399-426.

Lipmann, F. \& Tuttle, L. C. (1945). A specific micromethod for determination of acyl-phosphates. J Biol Chem 159, 21-28.

Lou, J., Dawson, K. A. \& Strobel, H. J. (1996). Role of phosphorolytic cleavage in cellobiose and cellodextrin metabolism by the ruminal bacterium Prevotella ruminicola. Appl Environ Microbiol 62, 1770-1773.

Lovitt, R. W., Shen, G. J. \& Zeikus, J. G. (1988). Ethanol production by thermophilic bacteria: biochemical basis for ethanol and hydrogen tolerance in Clostridium thermohydrosulfuricum. J Bacteriol 170, 2809-2815.

Miller, G. L. (1959). Use of dinitrosalicylic acid reagent for determination of reducing sugars. Anal Chem 31, 426-428.

Mortenson, L. E., Valentine, R. C. \& Carnahan, J. E. (1963). Ferredoxin in the phosphoroclastic reaction of pyruvic acid and its relation to nitrogen fixation in Clostridium pasteurianum. J Biol Chem 238, 794-800. 
Morvan, B., Rieu-Lesme, F., Fonty, G. \& Gouet, P. (1996). In vitro interactions between rumen $\mathrm{H}_{2}$-producing cellulolytic microorganisms and $\mathrm{H}_{2}$-utilizing acetogenic and sulfate reducing bacteria. Anaerobe 2, 175-180.

Ng, T. \& Zeikus, J. G. (1982). Differential metabolism of cellobiose and glucose by Clostridium thermocellum and Clostridium thermobydrosulfuricum. J Bacteriol 150, 1391-1399.

Petitdemange, H., Cherrier, C., Raval, G. \& Gay, R. (1976). Regulation of the NADH and NADPH-ferredoxin oxidoreductases in Clostridia of the butyric group. Biochim Biophys Acta 421, 334-347.

Petitdemange, E., Caillet, F., Giallo, J. \& Gaudin, C. (1984). Clostridium cellulolyticum sp. nov., a cellulolytic mesophilic species from decayed grass. Int J Syst Bacteriol 34, 155-159.

Robson, R. L., Robson, R. M. \& Morris, J. G. (1974). The biosynthesis of granulose by Clostridium pasteurianum. Biochem J 144, 503-511.

Russell, J. B., Bond, D. R. \& Cook, G. M. (1996). The fructose diphosphate/phosphate regulation of carbohydrate metabolism in low G $+C$ Gram-positive anaerobes. Res Microbiol 147, 528-535.

Schimz, K. L., Broll, B. \& John, B. (1983). Cellobiose phosphorylase (EC 2.4.1.20) of Cellulomonas: occurrence, induction, and its role in cellobiose metabolism. Arch Microbiol 135, 241-249.

Strobel, H. J. (1995). Growth of the thermophilic bacterium Clostridium thermocellum in continuous culture. Curr Microbiol 31, 210-214.

Strobel, H. J., Caldwell, F. C. \& Dawson, K. A. (1995). Carbo- hydrate transport by the anaerobic thermophile Clostridium thermocellum LQRI. Appl Environ Microbiol 61, 4012-4015.

Thauer, R. K., Ruppecht, E., Ohrloff, C., Jungermann, K. \& Decker, K. (1971). Regulation of the reduced nicotinamide adenine dinucleotide phosphate-ferredoxin reductase system in Clostridium kluyveri. J Biol Chem 246, 954-959.

Thurston, B., Dawson, K. A. \& Strobel, H. J. (1993). Cellobiose versus glucose utilization by the ruminial bacterium Ruminococcus albus. Appl Environ Microbiol 59, 2631-2637.

Vasconcelos, I., Girbal, L. \& Soucaille, P. (1994). Regulation of carbon and electron flow in Clostridium acetobutylicum grown in chemostat culture at neutral $\mathrm{pH}$ on mixtures of glucose and glycerol. J Bacteriol 176, 1443-1450.

Weimer, P. J. (1996). Why don't ruminal bacteria digest cellulose faster? J Dairy Sci 79, 1496-1502.

Wells, J. E., Russel, J. B., Shi, Y. \& Weimer, P. J. (1995). Cellodextrin efflux by the cellulolytic ruminal bacterium Fibrobacter succinogenes and its potential role in the growth of non-adherent bacteria. Appl Environ Microbiol 61, 1757-1762.

Wimpenny, J. W. T. \& Firth, A. (1972). Levels of nicotinamide adenine dinucleotide in facultative bacteria and the effect of oxygen. J Bacteriol 111, 24-32.

Wolin, M. J. \& Miller, T. L. (1988). Microbe-microbe interactions. In The Rumen Microbial Ecosystem, pp. 361-386. Edited by P. N. Hobson. London: Elsevier.

Received 13 June 1997; revised 6 October 1997; accepted 7 October 1997. 